vacant, some 600 applications were received for the vacant post, one of them actually being a worthy minister of a local Methodist connection. This shows the loose manner in which forest appointments had come to be regarded in this country. At that time there were probably not a dozen quite qualified foresters available in the whole of Britain.

Rules are framed for the maintenance of experimental plots in private forests. It is possible that in some cases useful purposes may be served by these rules; but it may be anticipated that most frequently we shall find the private forest owner conducting useful experiments in his own forests; and the forest officers, with their wider facilities, carrying on their own experiments in the State forests.

The third reference relates to the training of woodmen, both foremen woodmen and the more fortunate men whose lot it is to work with their own hands. Those who have had experience of the excellent training given in the Government school in the Forest of Dean would endorse all that is here said in its favour. The two forest schools, in the Forest of Dean and in the Chopwell Woods (county of Durham), provide for the training of about fourteen men yearly. We heartily endorse the recommendation that increased provision should be made for the training of men of their type. The census of I90I returned 12,035 woodmen employed in England and Wales.

The appearance of this Forestry Blue-book is opportune; it shows that $\mathrm{Mr}$. Runciman is actuated by an earnest wish to break away from the difficulties and delays that have so long beset British forestry. It is indeed time that the first sod in practical British forestry were turned. While the Development Commission, with its grant of $500,000 l$. yearly, has been running for three years, no beginning in practical State forestry has yet been made in Britain.

It is not evident from a perusal of the Blue-book why there should be further delay. The obvious course to be followed now is at once to open negotiations for the acquiring of land-either by direct negotiation, or by purchase as it comes into the market; and, so soon as an area has been secured, to depute the competent forest officials in the Whitehall Forest Office to proceed with the planting, in consultation with local opinion and experience. The examination of sites for State forests seems to offer scope for the energies of the five forest advisors recently appointed to the five forest areas into which England and Wales have been divided. These forest advisors are stationed at Oxford, Cambridge, Cirencester, Bangor, and Newcastle.

Following the practice of other countries, the State forest nurseries referred to in the Blue-book should be initiated, as early as may be; not only for the supply of young trees at economical rates for planting in the State forest, but for free issue to private forest owners, and to such municipal or other public bodies as may be disposed to undertake forest planting on their own account. The private forest owner in Britain has had a hard time these last years, with falling prices for timber and underwood, and increased taxation. The woodlands that he maintains are a national benefit, and he may well ask that the State should now help him with something more substantial than good advice in forestry!

A somewhat pressing question that the Advisory Committee has not yet touched upon is what monetary contribution, if any, should be allowed to municipal (or other corporate) forest planters by way of grant-in-aid, in the case of loss on their forest planting. India and Cape Colony are, in State forestry, some thirty years ahead of this country and the other British Colonies. For many years in Cape Colony NO. $228 \mathrm{I}$, VOL. 9I] municipal and other non-private planting has been aided on the $I l$. for $I l$. principle; that is to say, to every $r l$. of approved forest expenditure Government has added another $\mathrm{I} l$. With this contribution the State retains certain guarantees for the proper management of the forest or trees planted.

It is, as we have seen, now three years since the Development Commission obtained the grant of half a million a year for developing the natural resources of the country in various ways, the most lasting and far-reaching of these ways being forestry. During the first year provision was made for the planting of about ten square miles of forest in Ireland; but in Great Britain to this day no decided step has been taken in practical State forestry. We may therefore express the very earnest wish that, useful though the contemplated forest surveys may be, they will not be allowed to delay, for one day, the initiation of State forestry in Britain.

In the present season of the year, England is beautiful, almost in proportion to its woodedness! Every consideration of sentiment and hard fact demands the beginning, without further delay, of practical afforestation.

\section{ORNITHOLOGICAL NOTES.}

$\mathrm{I}$ view of persistent reports as to the marked 1 decrease, or even disappearance, of the landrail, or corncrake, as a breeding bird in many parts of the country, more especially the eastern and southeastern counties, the editors have issued with the June number of British Birds a schedule of inquiries on this matter. In a covering note Dr. Ticehurst points out that answers should be strictly limited to the presence or absence, now or in the past, and the relative numbers and changes in numbers, of breeding birds in different districts.

A beautifully illustrated article on the albatrosses of Laysan Island, in the South Pacific, appears in the April number of The American Museum Journal, based on a visit paid to that wonderful bird-resort by Mr. H. B. Dill in I9rI. In spite of periodical raids by plumage-hunters, the albatrosses still retain their original lack of fear, parties of them walking up to a visitor as if to greet him. Some idea of the vast numbers of sea-birds on the island may be gathered from an estimate that their daily product of guano is about Ioo tons. Some years ago a company was started to work this guano, but the venture was not a success, owing to the fact that the frequent rains wash out a large proportion of the ammonia from the deposits.

To the April number of The Emu (vol. xii., part 4 ) Dr. R. W. Shufeldt contributes an illustrated article on the osteology of the Cape Barron goose (Cereopsis novae-hollandiae). Although the skull presents certain well-marked peculiarities, the rest of the skeleton is that of a typical goose. The genus has been assigned to a special subfamily, but the affinities of the bird are clearly with the snow-goose (Chen hyperboreus).

According to The Christian Science Monitor, Boston, Mass., of May 29, Mr. R. C. Murphy has returned to New York from an ornithological expedition to South Georgia, bringing with him 500 skins and skeletons of large sea-birds, while others are to follow. These are to be divided between the American Museum of Natural History and the Brooklyn Institute of Arts and Sciences. Mr. Murphy states that on a small island a mile in diameter he has seen 4000 pairs of birds nesting on the ground. The principal specimens represent albatrosses, petrels, and three kinds of penguins.
R. L. 